\title{
Federal budget light on initiatives for health, research
}

Previously published at www.cmaj.ca

$\mathrm{T}$ he central message in the federal government's Mar. 4 budget was simple and straightforward: Canadians must brace for deficit-reducing budget cuts — but not just yet.

"Canadian families and business have accepted the need for restraint. Fairness requires that government too should have to keep costs under control," Finance Minister Jim Flaherty said in his fiscal blueprint for 2010/11, Leading the Way on Jobs and Growth (www.budget .gc.ca/2010/plan/toc-tdm-eng.html).

The federal government will proceed with previously scheduled investments under its two-year economic stimulus plan and with measures to deregulate the market and open the economy to foreign investors, while spending cautiously on new programs, according to the budget documents and an array of Finance Department officials at background briefings.

That translates into little in the way of new health or research initiatives, although Flaherty did take tentative steps toward resolving the medical isotope supply problem and provided modest relief to help offset scheduled cuts in the granting council budgets.

Overall spending for fiscal 2010/11 will rise by $\$ 12.8$ billion to $\$ 280.5$ billion, largely as a consequence of the economic stimulus plan announced in the 2009 federal budget (CMAJ 2009. DOI:10.1503/cmaj.090166). The government will run a deficit of $\$ 49.2$ billion in fiscal 2010/11 and the debt load will rise to $\$ 566.7$ billion.

Medical isotopes were among the few health-related areas to draw government attention.

Atomic Energy of Canada Ltd. received a $\$ 300$-million funding boost and although the specifics haven't yet been ironed out, Finance officials, who speak on condition of anonymity during the background budget briefings, said that about $\$ 50$ million of that is ticketed for ongoing repairs of

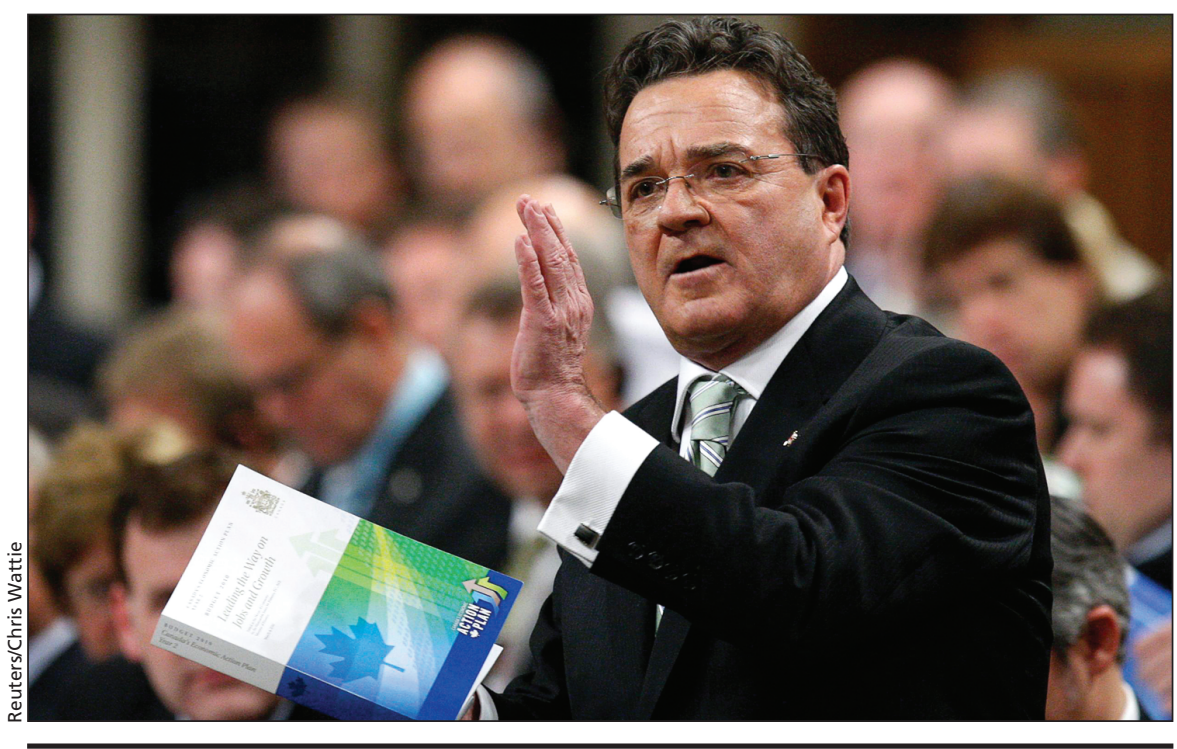

Finance Minister Jim Flaherty holds a copy of his budget during debate in the House of Commons on Parliament Hill in Ottawa, Ontario.

the troubled National Research Universal reactor in Chalk River, Ontario, which is set to be out of commission until late April.

The government also vowed to spend \$19 million in fiscal 2010/11 and \$29 million in fiscal 2011/12 to explore "new avenues for the production and use of medical isotopes." That includes \$35 million for Natural Resources Canada to support research on new forms of isotope production, \$10 million for the Canadian Institutes of Health Research (CIHR) to develop a "clinical trials network to help move research on isotopes and imaging technologies into clinical practice," and \$3 million for Health Canada on projects to "optimize the use of medical isotopes in the health system."

Finance officials said it will be up to Natural Resources to determine whether to use the monies to develop a new means of producing isotopes for example, by using cyclotrons - or to promote the development of production methods using low-enriched uranium, as is the case with United States plans (CMAJ 2010. DOI:10.1503 /cmaj.109-3187).
Elsewhere on the health front, the government:

- Committed \$285 million over two years to renew five expiring Aboriginal health programs: the Aboriginal Diabetes Initiative, the Aboriginal Youth Suicide Prevention Strategy, maternal and child health, the Aboriginal Health Human Resources Initiative and the Aboriginal Health Transition Fund.

- Will spend $\$ 60$ million over two years to extend a program that helps northern communities develop community health services.

- Will provide $\$ 45$ million over two years to offset the cost of shipping healthy food to isolated northern communities.

- Proposed to save $\$ 40$ million a year by making most forms of cosmetic surgery ineligible for medical expense tax credits, under which Canadians are allowed to claim 15\% of outlays that exceed the lesser of $\$ 2024$ or 3\% of their net income.

- Will impose the goods and services tax on cosmetic procedures.

- Will proceed with its 2009 promise to allocate an additional $\$ 500$ million to 
Canada Health Infoway, in charge of building a pan-Canadian infrastructure for electronic health records (CMAJ 2010: DOI:10.1503/cmaj.109-3183).

Flaherty also said federal transfers to the provinces for health care through 2014 will be exempt from the coming deficit reduction exercise, in accord with the provisions of the 2004 federal-provincial health care agreement, the 10-Year Plan to Strengthen Health Care.

Canadian Healthcare Association President Pamela Fralick dubbed the budget "good news with some gaps," adding that the commitment to spare health transfers was welcome but there were few concrete health prevention measures, little monies for seniors' health programs and nothing to address forthcoming shortages in health human resources.

"We don't see enough in the budget on that front," she said. "There's all sorts of areas where we believe we need more federal leadership and they are silent on those."

Canadian Medical Association President Dr. Anne Doig was encouraged by the renewal of funding for Aboriginal health programs but uncertain whether allocations for medical isotope production and supply will be adequate, given the demand.

"I hope that the money that's been designated for isotopes is going to be a positive," Doig said. "I guess it remains to be seen exactly what the government intends to do with that money and whether or not it will meet our needs in the long term and ensure sustainability, not only for Canadian nuclear medicine physicians but also for our international colleagues."

\section{Research initiatives}

Other research-related measures in the 2010/11 federal budget:

\section{Health research}

- Genome Canada will receive $\$ 75$ million for continued support of its regional innovation centres and to launch a new competition focused on forestry and environmental genomics research.

- Although funding for existing graduate and master's scholarship programs was not bolstered, the government vowed to set aside $\$ 45$ million over five years for the granting councils to establish a "new and prestigious post-doctoral fellowships program to attract top-level talent to Canada." The fellowships will be awarded at a level of $\$ 70000$ per year for two years, as compared with a $\$ 35000$ level for existing postgraduate scholarships. The program is expected to fund 140 fellowships annually.

- $\$ 9$ million over two years to help the non-for-profit Rick Hansen Foundation develop an institute for spinal cord research.

\section{Other research}

- \$18 million over five years "to commence the pre-construction design phase" for an Arctic research station. The government had set aside \$2 million in fiscal 2009/10 to conduct a feasibility study for the proposed station (CMAJ 2009. DOI:10.1503/cmaj.081815).

- $\$ 126$ million over five years for core operations at the Tri-University Meson Facility in British Columbia.

- $\$ 397$ million over five years for the Canadian Space Agency to develop the RADARSAT Constellation Mission, which proposes to generate radar images through the use of multiple satellites.

- An additional \$15 million a year to the College and Community Innovation Program, which funds joint research collaborations between community colleges and businesses.

- $\$ 8$ million over two years to extend the International Science and Technology Partnerships Program, which now supports collaborative research projects in India, China and Brazil.

\section{Look at HUMIRA for Crohn's disease}

\section{STEP 1: Start with 4}

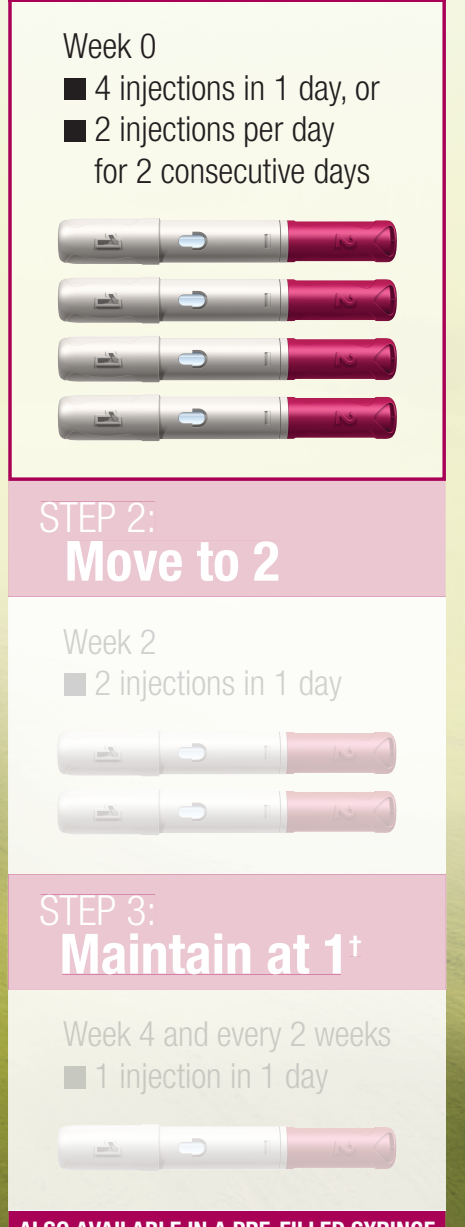

HUMIRA every 2 weeks. Sustained power

with subcutaneous self-injection. ${ }^{\dagger}$

t The use of HUMIRA in CD beyond one year has

not been evaluated in controlled clinical studies

\section{HUMIRA}


It was a similar case of mixed and modest blessings for the research granting councils. CIHR, the Natural Sciences and Engineering Research Council (NSERC) and the Social Sciences and Humanities Research Council (SSHRC) received a collective $\$ 32$ million - \$16 million, \$13 million and \$3 million, respectively — increase in their base operating budgets. But that doesn't offset the collective \$43-million hit they took for fiscal 2010/11 or the collective \$87.1-million hit they'll take for fiscal 2011/12 as a result of measures announced in the 2009 budget. The net effect is a reduction in the actual amounts available for research operating grants, albeit not as severe as originally scheduled.

'It doesn't even begin to keep up with inflation, let alone offset last year's cuts," says Jim Turk, executivedirector of the Canadian Association of University Teachers.

Nor was there any sign of money for CIHR President Dr. Alain Beaudet's proposal to lay the groundwork for a national initiative on Alzheimer disease and related dementias (CMAJ 2010. DOI:10.1503/cmaj.109-3064 and CMAJ
2009. DOI:10.1503/cmaj.091124).

Finance officials say the government no longer disaggregates granting council operating grant allocations in the overall council budgets, which include funds for a host of training and scholarship programs as well as other special allocations, such as money for targeted industry partnership programs or the Canada Research Chairs program. The upshot, the officials said, is that CIHR's global budget will rise to $\$ 986.7$ million from $\$ 980.3$ million, while NSERC's will decline to $\$ 1.022$ billion from $\$ 1.039$ billion and SSHRC's will drop to $\$ 680$ million from $\$ 685.1$ million. The SSHRC budget includes government funds for the Indirect Costs of Research Program, which will rise $\$ 8$ million to $\$ 333$ million, to help universities allay administrative and overhead costs associated with conducting research.

"It's all good news," said one veteran Finance official.

And, as federal governments for decades have been wont to do in the face of calls to invest heavily in research, Prime Minister Stephen Harper's Conservative government announced it will launch yet another review of federal science spending to again determine if taxpayers are getting the best bang for their buck.

The rationale for launching the exercise is to align outlays largely along commercialization objectives, the budget states. "To ensure that federal funding is yielding maximum benefits for Canadians, the Government, in close consultation with business leaders from all sectors and our provincial partners, will conduct a comprehensive review of all federal support for R\&D to improve its contribution to innovation and to economic opportunities for business. This review will inform future decisions regarding federal support for R\&D. The Government is currently developing the terms of reference for the review."

Turk says the clear intent is to find more ways of linking university research to industry. "They're throwing more and more public money into programs at the granting councils and otherwise to divert people into partnerships with industry." — Wayne Kondro, CMAJ

DOI:10.1503/cmaj.109-3201

\section{Global shift toward increased biovigilance}

Previously published at www.cmaj.ca

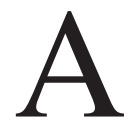
global movement toward increased biovigilance is resulting in the rapid rollout of Canadian, American and European initiatives aimed at developing national surveillance systems for cells, tissues and organs.

The Public Health Agency of Canada is leading the development of a reporting and surveillance system that will track and analyze adverse events in the transplantation of products of human origin. The system will collect data on moderate and severe adverse events eventually expanding to include serious errors and near misses - to monitor trends in known and emerging risks and reduce the transmission of infectious diseases due to transplantation.

Nova Scotia, Quebec and Alberta were recently chosen as pilot provinces

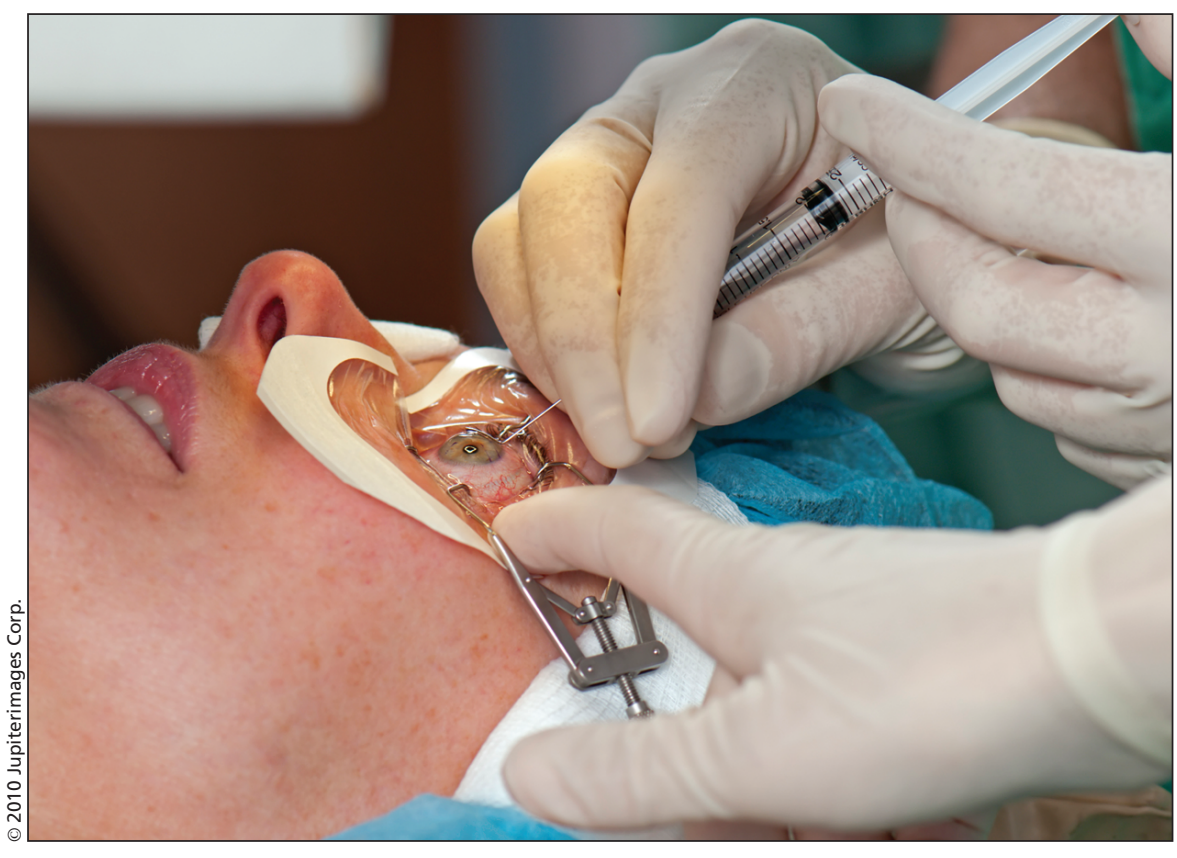

Cornea transplants are among the most common forms of tissue transplantation. 